\title{
DESCRIPTION OF UTA MEARNSI, A NEW LIZARD FROM CALIFORNIA.
}

\author{
By Leonhard SteJNeger, \\ Curator of the Department of Reptiles and Batrachians
}

THE accidental nature of reptile collecting is well illustrated by the discovery of this very conspicuous and distinct species in a region which has been visited before by some of our best collectors.

The trenchant character of the distinctions between the present species and its nearest ally inhabiting the Cape St. Lucas region emphasizes the gap between the Cape region proper and the rest of the Lower California peninsula.

This discovery, moreover, is quite important, inasmuch as it bridges over the supposed difference between Uta thalassina and the other species of the genus Uta. Boulenger, in 1885, * established the genus Fetrosaurus for that species because of its small caudal scales, the smooth ness of the dorsal granules, and the absence of denticulation on the border of the posterior gular fold. The present species, however, has the caudal scales large, keeled, and spinose, in fact, exactly as in the typical species of the genus Uta; the dorsal scales are larger, more convex, nearly tubercular on the sides, thus approaching the other Utas, while the question of denticulation to the collar is one essentially of degree only. However, the species which I am dedicating to its discoverer, Dr. E. A. Mearns, U. S. A., naturalist of the International Boundary Commission (United States and Mexico), is undoubtedly nearly related to $U$. thalassina and more so than to any of the other species of the genus.

UTA MEARNSI, new species.

Diagnosis.-Dorsal scales uniform, small, smooth; edge of gular fold without enlarged scales; four or five very long and pointed scales on anterior border of ear-opening; tail with large, strongly keeled, spinose scales; scales on arms and legs strongly keeled. One well-marked

* Catalogue of the Lizards in the British Museum, II, p. 205.

Proceedings of the U.S. National Museum, Vol. XVII-No. 1020.

[Advance sheets of this paper were published November 30, 1894.] 
black line from shoulder to shoulder across the back; tail above, regularly cross-barred with black.

Habitat.-East slope of Coast Range on boundary line between California and Lower California.

Type.-No. 21882, U. S. N. M., Summit of Coast Range, United States and Mexican boundary line, California.

Description of the type.-Female. Head moderately depressed, snout narrow; eanthus rostralis well marked; nostrils rather large, almost superior, much nearer to the tip of the snout than to the orbit; earopening large, with four very long, triangular, pointed scales and three smaller ones in front; head-shields smooth; frontal divided trans. versely; about eight of the posterior supraorbital scales enlarged, one being particularly large, these separated from the frontals by a single series of granules; superciliaries, particularly the anterior ones, very long and narrow; a very long and narrow infraorbital; occipital as large as ear-opening; supralabials six, and, like rostral, very wide and low; infralabials scarcely higher, but considerably narrower; scales on throat small, rounded, smooth, those on the middle and near the edge of the gular fold somewhat larger; only one transverse gular fold, not denticulated; sides of neck strongly folded; scales on back and sides rather large, rounded and convex granules, those on lower surface of body larger, flat, hexagonal; limbs with enlarged, keeled scales, and rather long, the anterior when pressed to the side reaching to the insertion of the thigh, the posterior when stretched forward reaching to the orbit; twenty femoral pores on each side; tail depressed at base, slender, its length more than one and three-fourths that of head and body, covered with rings of rather large scales which, on the upper surface and the sides, are provided with a very strong keel ending in a projecting spine.

Color above olive, more brownish on head and tail, with irregular dusky, nearly blackish, cross-bands; lighter spots, or marblings, on the interspaces; a very distinctly marked, straight, and intensely black band from shoulder to shoulder across the back; limbs irregularly crossbanded with dusky; basal two-thirds of tail pale browuish olive with wide black cross-bars, terminal third uniformly blackish; under surface greenish white, bluish on flanks with lighter dots; chin and throat with a network of bluish gray.

Dimensions.-Total length, $229 \mathrm{~mm}$; head and body, $79 \mathrm{~mm}$; tail, $150 \mathrm{~mm}$.; fore limb, $37 \mathrm{~mm}$; hind limb, $61 \mathrm{~mm}$.

Variation.-In addition to the type Or. Mearns' collection contains six other specimens which fully establish the characters of the species. The individual variation is comparatively slight, and but few deviations from the above description of the type are noticed. In some specimens there seems to be a slight anterior gular fold, but it is not marked by any difference in the scutellation. In one specimen the frontal is not divided transversely, and in about one-half, the large supraoculars are 
separated from the frontal by a double row of granules. Other discrepancies will be noticed in the list of specimens given below.

The males have enlarged postanal scales.

The individual differences of coloration consist mainly in the outline and intensity of the dusky cross-bars, while the black collar is equally distinct in all.

The sexes are alike in color, except thatt he blue flank-patch is somewhat darker and wider in the males.

Comparison with Uta thalassina.-Although closely allied to Uta thalassina, described in 1863 by Prof. Cope from specimens collected at Cape St. Lucas, the present species differs in many essential points, most of which have been indicated in the diagnosis.

In addition to these it may be remarked that the granules on the back are larger in Uta mearnsi, but that the ventral scales are smaller; it lacks the well-defined anterior gular fold of $U$. thalassina; the legs and tail are comparatively longer, and the femoral pores are more numerous; each of the latter, moreover, is bordered behind by two granules, while in $U$. thalassina there are three. The last mentioned species appears also to be much the larger, as the specimens collected by Dr. Mearns seem to be quite adult.

The most striking differences, however, are the long preauricular spines and the large, strongly keeled, and spinous caudal scales of Uta mearnsi, together with the absence of the two posterior dorsal black bands so characteristic of $U$. thalassina.

Geographical distribution.-Dr. Mearns found this species "extremely plentiful" among the rocks on the eastern slope of the Coast Range of California, near the Mexican boundary line, from the lowest water in the canyon at the base to the summit. So far this is the only locality where it is known to have been taken. I would suggest, however, that it was most probably this species which Mr. Lockington has recorded from Ensenada, Todos Santos Bay, Lower California, 75 miles south east of San Diego (Amer. Natural., 1880, p. 295), as Uta thalassina.

List of specimens.

\begin{tabular}{|c|c|c|c|c|c|c|}
\hline $\begin{array}{l}\text { Catalogue } \\
\text { number } \\
\text { U.S.N.M. }\end{array}$ & Sex. & $\begin{array}{l}\text { Locality: Coast Range, California, near } \\
\text { the Mexican boundary. }\end{array}$ & $\begin{array}{l}\text { Body } \\
\text { and } \\
\text { head. }\end{array}$ & Tail. & $\begin{array}{c}\text { Femoral } \\
\text { pores. }\end{array}$ & $\begin{array}{l}\text { Supra. } \\
\text { labials. }\end{array}$ \\
\hline $\begin{array}{l}21882 \\
21883 \\
21884 \\
21885 \\
21886 \\
21887 \\
21888\end{array}$ & $\begin{array}{l}\text { Female ... } \\
\text { Female .... } \\
\text { Female } \ldots . \\
\text { Female } \ldots . . \\
\text { Male...... } \\
\text { Male....... } \\
\text { Female... }\end{array}$ & 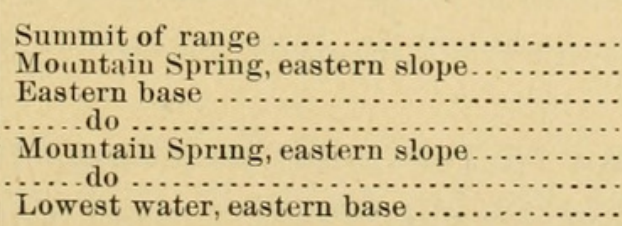 & $\begin{array}{r}m m_{1} \\
79 \\
74 \\
78 \\
75 \\
79 \\
88 \\
73\end{array}$ & $\begin{array}{l}m m . \\
150 \\
\left({ }^{*}\right) \\
\left(^{*}\right) \\
140 \\
\left({ }^{*}\right) \\
\left({ }^{*}\right) \\
\left(^{*}\right)\end{array}$ & $\begin{array}{r}20 \\
22 \\
20 \\
21-22 \\
23-25 \\
21-24 \\
19-20\end{array}$ & $\begin{array}{r}6 \\
5-6 \\
5 \\
5 \\
5-6 \\
6 \\
6\end{array}$ \\
\hline
\end{tabular}

* Tail reproduced 


\section{$2 \mathrm{BHL}$ Biodiversity Heritage Library}

Stejneger, Leonhard. 1894. "Description of Uta mearnsi. A new lizard from California." Proceedings of the United States National Museum 17, 589-591.

View This Item Online: https://www.biodiversitylibrary.org/item/53454

Permalink: https://www.biodiversitylibrary.org/partpdf/52155

\section{Holding Institution}

Smithsonian Libraries

\section{Sponsored by}

Smithsonian

\section{Copyright \& Reuse}

Copyright Status: Public domain. The BHL considers that this work is no longer under copyright protection.

This document was created from content at the Biodiversity Heritage Library, the world's largest open access digital library for biodiversity literature and archives. Visit BHL at https://www.biodiversitylibrary.org. 